\title{
LACTONES OF Artemisia scoparia
}

$$
\text { E. F. Nesmelova and G. P. Sidyakin }
$$

UDC 547.588.25

We have investigated Artemisia scoparia W. et K. growing in Uzbekistan and in southern Kazakhstan for its lactone content.

From a petroleum ether extract of the flower heads collected in July (Chimkent oblast), we isolated a coumarin - scoparone [1] $(0.25 \%$ of the weight of the dry plant); from a petroleum ether extract of the leaves and buds collected in July (Tashkent oblast) we isolated a hydrocarbon with $\mathrm{mp} 79-80^{\circ} \mathrm{C}(0.126 \%$ of the weight of the dry plant).

The mother liquor was chromatographed on alumina (neutral, activity grade III-IV, $57: 1$ ). Elution was performed with petroleum ether, giving a colored crystallizing oil the UV spectrum of which showed the presence of polyynes in it $\left(\lambda_{\max } 230-235,238-240,245,250,256\right.$, and 340-346 nm) [2]. The oil was rechromatographed in silica gel $(47: 1)$. On elution with petroleum ether, the zones fluorescing bluishyellow in UV light deposited faintly colored crystals with the composition $\mathrm{C}_{13} \mathrm{H}_{10} \mathrm{O}_{2}(0.016 \%$ of the weight of the dry plant) with $\mathrm{mp} 122-123^{\circ} \mathrm{C}$ (petroleum ether), $\lambda_{\max } 230,241,256,265,275,326 \mathrm{~nm} ; \nu_{\max } 1730 \mathrm{~cm}^{-1}$ (CO), $1660 \mathrm{~cm}^{-1}(\mathrm{C}=\mathrm{C}), 1605,1570$, and $1485 \mathrm{~cm}^{-1}$ (arom.). The melting point and the IR and UV spectra were similar to those for the isocoumarin capillarin isolated previously from the epigeal part of A. capillaris and from the roots of Chrysanthemum trutescens L. [3, 4]. The hydrogenation of capillarin $\overline{b y} \overline{\text { Adams' }}$ method in ethanolic solution gave tetrahydrocapillarin, which proved to be identical with the dihydro derivative of artemidin [5].

A chloroform extract of the roots collected in July (Tashkent oblast) after chromatographic purification on alumina (acidic, activity grade $\mathrm{II}, 60: 1)$ and then on silica gel $(50: 1)$, gave a lactone with mp 146$148^{\circ} \mathrm{C}$ (ether) exhibiting a bluish-gray fluorescence in UV light. Thin-layer chromatography on silica gel $\mathrm{G}$ [toluene-ethyl acetate (10:1)] gave a single spot with $\mathrm{R}_{f} 0.01-0.02, \nu_{\max } 3440 \mathrm{~cm}^{-1}(\mathrm{OH}), 1720 \mathrm{~cm}^{-1}$ (CO), $1618 \mathrm{~cm}^{-1}$ (C =C), 1578, 1512, $14601420 \mathrm{~cm}^{-1}$ (arom.); $\lambda_{\max }, \mathrm{nm}, 213,226-235$ (shoulder), 325.

From the combined methanolic extractive substances of the roots collected in June (Chimkent oblast) we obtained an ether-insoluble fraction which was treated with $10 \%$ caustic potash in methanol and, after standing for $24 \mathrm{~h}$ and acidification, was extracted with ether. The ethereal extract was chromatographed twice on silica gel $(30: 1$ and $40: 1)$. An ethereal eluate deposited crystals with $\mathrm{mp}$ about $190^{\circ} \mathrm{C}$ (chloroform) $\left(0.070 \%\right.$ of the weight of the dry plant), $\nu_{\max } 1640$ and $1620 \mathrm{~cm}^{-1}$ (two carbonyl groups characteristic for flavonoids), $1600 \mathrm{~cm}^{-1}(\mathrm{C}=\mathrm{C}), 1525 \mathrm{~cm}^{-1}$ (arom.).

In addition, the roots yielded $\beta$-sitosterol $(0.034-0.009 \%$ of the weight of the dry plant) and oxalic acid $(0.5 \%$ of the weight of the dry plant).

This is the first time that all the substances, except for scoparone, have been isolated from Artemisia scoparia.

\section{LITERATURE CITED}

1. D. B. Parihar and S. Dutt, Proc. Indian Acad. Sci., 26A, No. 2, 153 (1947).

2. Gen Nakaminami, Usp. Khim., 34, No. 3, 503 (1965).

3. Rokuro Harada, Sumio Nogichi, and Noboru Sugiyama, Nippon Kagaku Zas., 81, 654 (1960).

4. F. Bohleman and K. M. Kleine, Chem. Ber., 95, 602 (1962).

5. A. Mallabaev, I. M. Saitbaeva, and G. P. Sidyakin, Khim. Prirodn. Soedin., 6, 467, 531 (1970).

Order of the Red Banner of Labor Institute of the Chemistry of Plant Substances of the Academy of Sciences of the Uzbek SSR. Translated from Khimiya Prirodnykh Soedinenii, No. 3, pp. 376-377, May-June, 1971. Original article submitted February 17, 1971.

- 1973 Consultants Bureau, a division of Plenum Publishing Corporation, 227 West 17th Street, New York, N.Y. 10011. All rights reserved. This article cannot be reproduced for any purpose whatsoever without permission of the publisher. A copy of this article is available from the publisher for $\$ 15.00$. 